\title{
Mites of the genus Prozercon (Acari: Zerconidae) in Dilek Peninsula-Büyük Menderes Delta National Park (Turkey), with description of a new species
}

\author{
Büşra KEÇECİ1 (1), Raşit URHAN ${ }^{1}$ (i), Mehmet KARACA ${ }^{2,3}$ (1) \\ ${ }^{1}$ Department of Biology, Faculty of Science and Arts, Pamukkale University, Denizli, Turkey \\ ${ }^{2}$ Department of Electronic and Automation, Denizli Vocational School of Technical Sciences, Pamukkale University, Denizli, \\ Turkey \\ ${ }^{3}$ Corresponding author: karacamehmet@pau.edu.tr
}

Received: 7 December 2020

Accepted: 14 January 2021

Available online: 27 January 2021

ASBTRACT: In the present paper, zerconid mites of the genus Prozercon were collected from the Dilek Peninsula-Büyük Menderes Delta National Park, Didim County, Aydın Province (western Turkey). After identification processes, three Prozercon species were found in the research area, among them, P. didimensis sp. nov. was described and illustrated as a new species for the science. Also, altitude and habitat preferences of the species were given and discussed.

Keywords: Mesostigmata, zerconid mites, new species, preference, Didim, Aydın.

Zoobank: http://zoobank.org/739128D7-32B1-4FC4-B81E-BAF2C5BD2EB3

\section{INTRODUCTION}

Zerconid mites (Zerconidae), which is one of the important mite families of soil mesofauna in the Holarctic region, are represented with two genera (Prozercon and Zercon) and 129 species in Turkey (Urhan and Karaca, 2019, 2020; Urhan et al., 2020, 2021; Bulut, 2020; Keçeci, 2020). Most of these species are endemic to Turkey and have been found during long-term researches in the country, especially based on various results of M.Sc. and Ph.D. theses. On the other hand, in many parts of Turkey systematics and ecological researches are still ongoing on zerconid mites. Therefore, new species and records of zerconid mites are being increased day by day for the Turkish fauna.

National parks are protected areas in many countries in the world which include various kinds of floral and faunal elements, and are always great attractions for scientists. Turkey is a rich country in terms of number of national parks with 44 national parks, one of which is the Dilek Peninsula-Büyük Menderes Delta National Park, a protected area located in Kuşadası County of Aydın Province (western Turkey). No research on zerconid mites has been performed in this area so far. Therefore, the aim of this study is to reveal the species diversity of the family Zerconidae in that area systematically and ecologically.

In the present paper, diversity of these mites in the above-mentioned national park was investigated. A species list for the Prozercon species found in that area was given herein, including knowledge on their distributions, altitudinal and habitat preferences. Also, description and illustrations of a new species and a key for the Prozercon species in the research area were given.

\section{MATERIALS AND METHODS}

All materials of zerconid mites were collected from the Dilek Peninsula-Büyük Menderes Delta National Park in a period between December 2018 and May 2020 as part of a faunistic study. Sampling studies was carried out after obtaining legal permissions from the "Republic of Turkey Ministry of Forestry and Water Affairs, General Directorate of Nature Conservation and National Parks (72784983-488.04-51504)". For revealing species richness of zerconid mites in the research area, different materials (plant litter, soil and moss samples) were collected from suitable habitats, especially from forestland areas. All materials were taken from 97 different localities. The GPS data for collecting localities, including coordinates and altitudes, was taken using a Garmin GPSMap 62S.

All collected samples were transferred to the acarology laboratory of Pamukkale University for identification processes. Firstly, all collected materials were put in the Berlese-Tullgren funnels for extraction of mite specimens during 5-7 days. Zerconid specimens were selected using an Olympus SZ51. Then, they were preserved in $70 \%$ ethanol, cleared in $60 \%$ lactic acid, and finally mounted on microscope slides using Hoyer's medium. The specimens were identified using an Olympus CX41 and all illustrations were drawn with DP25 camera attached to an Olympus BX50 microscope. All examined Prozercon specimens were deposited at acarology laboratory of Pamukkale University, Denizli, Turkey. The idiosomal setation follows Lindquist and Evans (1965), with modifications for the caudal region as given by Lindquist and Moraza (1998). Terminology for idiosomal adenotaxy and poroidotaxy follows that of Johnston and Moraza (1991). All measurements, including scale bars of the figures, are given in micrometers $(\mu \mathrm{m})$. Abbreviation of DN was used for deutonymph specimens.

\section{RESULTS}

Family Zerconidae Canestrini, 1891

Genus Prozercon Sellnick, 1943 
Type species: Zercon fimbriatus C. L. Koch, 1839

Posterior parts of peritremal shields extending to setae $R 4$ or $R 5$. Two setae present on peritremal shields: $r 1$ short, smooth or finely plumose, $r 3$ short and smooth. No gap between peritremal shield and the edge of the podonotum. Adgenital shields absent. Opisthonotum with seven or eight pairs of marginal setae $(S 1+R 1-R 6$ or $S 1+$ R1-R7). Anterior margin of ventrianal shield always with two setae (Karaca et al., 2017).

\section{Prozercon didimensis sp. nov. (Figures 1-2)}

Zoobank: http://zoobank.org/8395C5CC-80D5-4BDE8D8C-C51DE33169E2

Type material. Holotype (female), soil and litter samples $27^{\circ} 20.381^{\prime}$ E, $85 \mathrm{~m}$ a.s.l., vicinity of Söke-Milas road, fork of Didim road, Aydın Province, 8 April 2020. Paratypes: 6 females, same data as holotype; 5 females, soil and litter samples under olive tree (Olea europaea), same data as holotype.

Diagnosis. Anterior margin of ventrianal shield with two pairs of setae. All podonotal setae finely barbed (except seta $j 5$ ). Seta $j 5$ short, smooth and needle-like. All opisthonotal setae finely barbed in various lengths, marginal setae shorter than others. Pores gdS2 located between setae $Z 2$ and $S 2, g d Z 3$ located between setae $J 4$ and $Z 4$, closer to Z4. Dorsal cavities weakly developed. Podonotum covered with tile-like and reticulate pattern, opisthonotum covered by irregular punctate pattern.

Female (Figs 1-2). Length (without gnathosoma) and width in holotype 305 and 232, respectively. Measurements of 11 paratypes: length 296-315, width 224-247. Dorsal fossae indistint and weakly sclerotized.

Dorsal side. (Fig. 1). Twenty pairs of setae present on podonotum: setae in $j$ series with six pairs, $z$ series with five pairs, $s$ series with six pairs and $r$ series with three pairs. All of them finely or densely plumose (except seta j5). Setae $j 1$ and $s 3$ markedly elongated, densely plumose and brush-like. Seta $j 5$ short, smooth and needle-like. Setae $j 2, s 1$ and $z 2$ shorter than other podonotal setae. Remaining podonotal setae approximately as the same length. Except seta $s 3$, all marginal setae in $r$ series situated as parallel to lateral margin of podonotum. Twenty one pairs of setae present on opisthonotum: setae in $J$ series with five pairs, $Z$ series with five pairs, $S$ series with five pairs and $R$ series with six pairs. All of them finely or densely plumose. In $J$ series, only seta $J 5$ reaching base of following seta. Seta $Z 5$ unilateral plumose in contrary of other setae in $J$ series, situated as parallel to posterior margin of opisthonotum. None of setae in $Z$ series reaching the base of following seta. Seta JV5 similar to Z5. None of setae in $S$ series reaching the base of following seta. All setae in $S$ series situated as parallel to lateral margin of opisthonotum. Seta $S 2$ not reaching lateral margin of opisthonotum, seta $S 3$ reaching lateral margin of opisthonotum, but setae $S 4$ and $S 5$ reaching beyond of opisthonotum. All marginal setae $(S 1+R 1-R 6)$ situated as parallel to lateral margin of opisthonotum. The interval between under strawberry tree (Arbutus sp.), 37²9.664' N,

setae Z5 and JV5 21-24. Length of the opisthonotal setae and distance between setal bases within longitudinal $J, Z$ and $S$ rows are given in Table 1 for female specimens of $P$. didimensis sp. nov.

Pores. (Fig. 1). On podonotum, pores $g d s 1$ located on the line connecting setae $j 3-s 1$, closer to $s 1$. Pores gdj4 located on the line connecting setae $j 4-z 4$, closer to $z 4$. Pores $g d s 4$ located on the line connecting setae $s 4-s 5$, closer to $s 5$. On opisthonotum, pores $g d Z 1$ located above the base of setae Z1. Pores $g d S 2$ located on the line connecting setae Z2-S2. Pores $g d Z 3$ located on the line connecting setae J4-Z4, closer to Z4. Pores $g d S 5$ located closer to base of setae $S 5$.

Ventral side. (Fig. 2). Chaetotaxy and shape of the peritrematal shields normal for the genus Prozercon. Posterolateral tips of peritrematal shield reaching the level of setae $R 2-R 3$. Peritrematal shield with two pairs of setae ( $r 1$ and $r 3$ ), both short, smooth and needle-like. Peritremes similar to reverse comma. Sternal shield with three pairs of setae (st1-3), genital shield with one seta (st5), and one seta (st4) present between sternal and epigynal shield, all of them short, smooth and needle-like. Glands gv2 absent between posterior section of genital shield and anterior section of ventrianal shield. Ventrianal shield with eight pairs of setae (JV1-JV3, ZV2-ZV4, JV4 and $A d)$ and one single postanal seta $(P a)$, all short, smooth and needle-like. Postanal seta as the longest on the ventrianal shield. Anterior margin of ventrianal shield with two setae (JV1).

Male and immature stages. Not found.

Etymology. The specific epithet 'didimensis' refers to the Didim County (Aydın Province) where the new species was collected.

Remarks. Prozercon didimensis sp. nov. is quite similar to P. banazensis Urhan, Karaca and Duran, 2015, P. erdogani Urhan, 2010 and P. martae Ujvári, 2010. The distinctive morphological features of these four species were given in Table 2.

Table 1. Maximum and minimum ranges of opisthonotal setae and the distances between their bases in $J, Z$, and $S$ rows of Prozercon didimensis sp. nov. (females).

\begin{tabular}{|c|c|c|c|c|c|}
\hline Setae & ㅇ & Setae & 우 & Seta & q \\
\hline$J 1$ & $20-21$ & Z1 & $16-18$ & S1 & $18-22$ \\
\hline$J 1-J 2$ & $25-31$ & Z1-Z2 & $35-38$ & $S 1-S 2$ & $20-25$ \\
\hline$J 2$ & $22-26$ & $Z 2$ & $15-18$ & $S 2$ & $18-20$ \\
\hline$J 2-J 3$ & $30-37$ & Z2-Z3 & $29-34$ & $S 2-S 3$ & $31-35$ \\
\hline J3 & $18-21$ & Z3 & $18-20$ & S3 & 18-19 \\
\hline J3-J4 & $22-27$ & Z3-Z4 & $17-23$ & $S 3-S 4$ & $22-29$ \\
\hline$J 4$ & $15-16$ & $Z 4$ & $11-12$ & $S 4$ & $18-21$ \\
\hline J4-J5 & $18-21$ & Z4-Z5 & $45-56$ & S4-S5 & $18-22$ \\
\hline$J 5$ & $12-15$ & $Z 5$ & $17-20$ & $S 5$ & $20-23$ \\
\hline
\end{tabular}

Acarological Studies 3 (1): 37-42, 2021 


\section{Prozercon yavuzi Urhan, 1998}

Materials examined: Three females: soil and litter samples under oak tree (Quercus sp.), 37³9.598' N, 276.434' D, $814 \mathrm{~m}$ a.s.l., vicinity of radar surveillance area of "Naval Forces Command", 10 December 2018. Nine females: soil and litter samples under sage-leaved rock-rose (Cistus salviifolius), $37^{\circ} 44.784^{\prime} \mathrm{N}, 27^{\circ} 20.967^{\prime} \mathrm{D}, 200 \mathrm{~m}$ a.s.l., vicinity of Söke-Davutlar neighborhoods road, 14 May 2019. One female: soil and litter samples under Turkish pine (Pinus brutia), 37³8.899' N, 27015.744' D, 10 m a.s.l., Yuvacaköy neighborhood, 14 May 2019. Four females and two males: soil and litter samples under olive tree (Olea europaea), $37^{\circ} 37.283^{\prime} \mathrm{N}, 27^{\circ} 11.763^{\prime} \mathrm{D}, 12 \mathrm{~m}$ a.s.l., vicinity of Tuzburgazı neighborhood, 14 May 2019. One female: soil and litter samples under oleaster-leafed pear (Pyrus

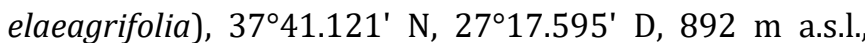
Dilek Mountain, 31 August 2019. One female: soil and litter samples under kermes oak (Quercus coccifera), $37^{\circ} 42.213^{\prime} \mathrm{N}, 27^{\circ} 17.990^{\prime} \mathrm{D}, 385 \mathrm{~m}$ a.s.l., vicinity of Kurşunlu Monastery, Davutlar neighborhood, 9 November 2019. Six females: soil and litter samples under holly oak (Quercus ilex), 37²2.624' N, 27018.512' D, 277 m a.s.l., vicinity of Kurşunlu Monastery, Davutlar neighborhood, 9 November 2019. One female: moss samples, $37^{\circ} 41.798^{\prime} \mathrm{N}, 27^{\circ} 9.436^{\prime}$ D, 21 m a.s.l., vicinity of Kavaklıburun Bay, 3 February 2020.

Turkish distribution: Aydın, Balıkesir, Denizli, İstanbul, Muğla (Karaca, 2015, 2021).

Known distribution: Turkey (Urhan, 1998), Crete, Greece (Ujvári, 2008, 2011).
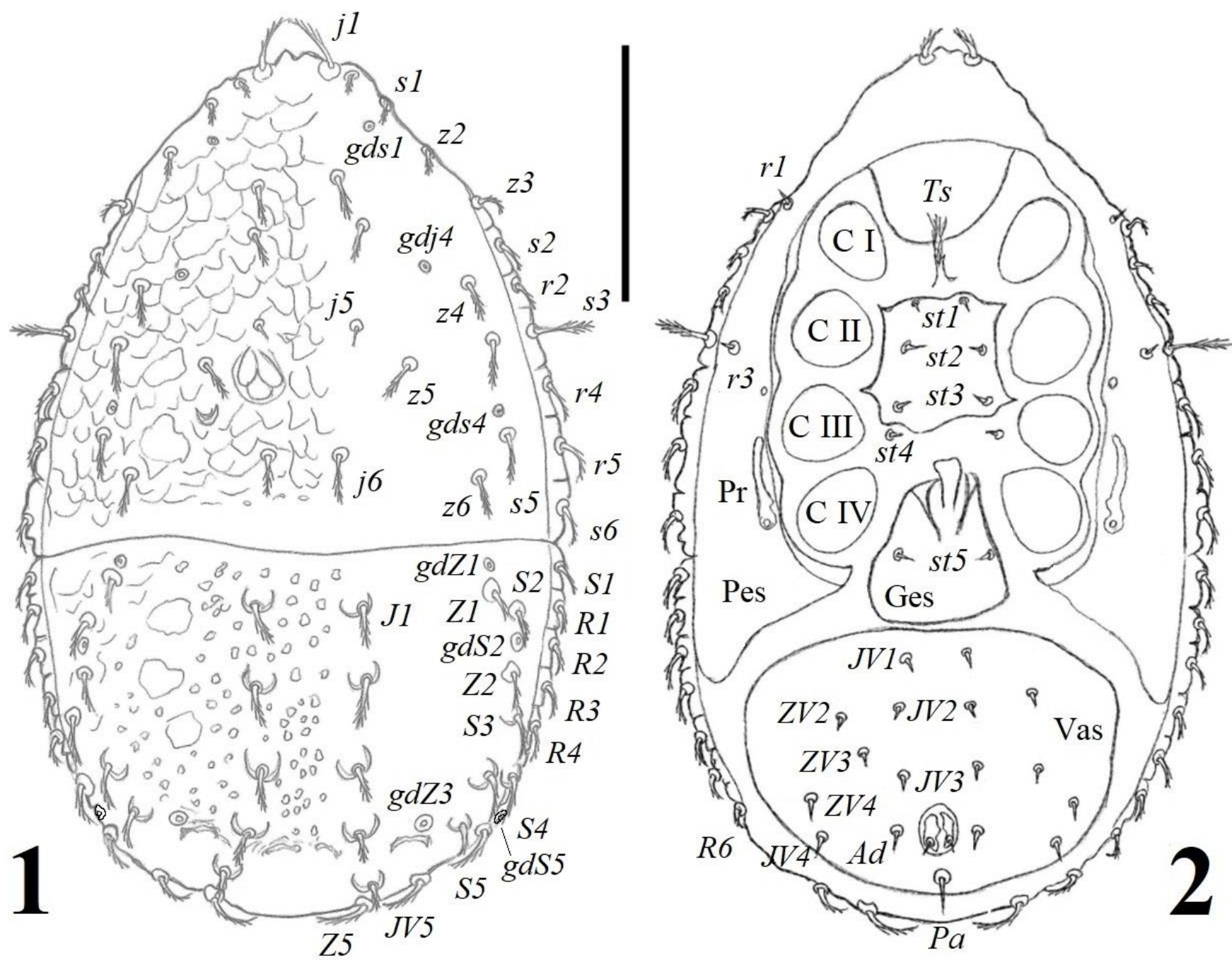

Figures 1-2. Prozercon didimensis sp. nov. (female) 1. Dorsal view, 2. Ventral views. Abbreviations: ( $r 1$ and $r 3$ ) peritremal setae, (Pr) peritreme, (Pes) peritremal shield, (Ts) tritosternum, (C I-C IV) endopodal shields, (st1-5) sternal setae, (Ges) genital shield, (Vas) ventrianal shield, (JV1-JV3, ZV2-ZV4 and JV4) ventrianal setae, (Ad) adanal setae and (Pa) postanal seta. Scale bar 100. 
Table 2. Morphological distinguishing characters for P. didimensis sp. nov., P. banazensis, P. erdogani and P. martae.

\begin{tabular}{|c|c|c|c|c|}
\hline Characters & $\begin{array}{l}\text { P. didimensis } \\
\text { sp. nov. }\end{array}$ & $\begin{array}{l}\text { P. banazensis } \\
\text { Urhan, Karaca and } \\
\text { Duran, } 2015\end{array}$ & $\begin{array}{l}\text { P. erdogani } \\
\text { Urhan, } 2010\end{array}$ & $\begin{array}{l}\text { P. martae } \\
\text { Ujvári, } 2010\end{array}$ \\
\hline Setae in $J$ series & $\begin{array}{l}\text { Only seta J5 reach to } \\
\text { base of following seta }\end{array}$ & $\begin{array}{l}\text { Except setae } J 1 \text { and } J 2 \text {, } \\
J 3-J 5 \text { reach to base of } \\
\text { following seta }\end{array}$ & $\begin{array}{l}\text { Except setae } J 1 \\
\text { and } J 2, J 3-J 5 \text { reach } \\
\text { to base of follow- } \\
\text { ing seta }\end{array}$ & $\begin{array}{l}\text { Except setae } J 1, J 2- \\
J 5 \text { reach to base of } \\
\text { following seta }\end{array}$ \\
\hline Seta J6 & $\begin{array}{l}\text { situated as parallel to } \\
\text { posterior margin of } \\
\text { opisthonotum }\end{array}$ & $\begin{array}{l}\text { situated as parallel to } \\
\text { posterior margin of } \\
\text { opisthonotum }\end{array}$ & $\begin{array}{l}\text { situated vertically } \\
\text { to posterior mar- } \\
\text { gin of opisthono- } \\
\text { tum }\end{array}$ & $\begin{array}{l}\text { situated vertically } \\
\text { to posterior mar- } \\
\text { gin of opisthono- } \\
\text { tum }\end{array}$ \\
\hline Seta Z3 & finely barbed & $\begin{array}{l}\text { phylliform and finely } \\
\text { serrate marginally }\end{array}$ & plumose & plumose \\
\hline Seta $S 2$ & finely barbed & finely barbed & plumose & plumose \\
\hline Seta $S 3$ & finely barbed & $\begin{array}{l}\text { phylliform and finely } \\
\text { serrate marginally or } \\
\text { smooth }\end{array}$ & absent & plumose \\
\hline Seta $S 4$ & $\begin{array}{l}\text { situated as parallel to } \\
\text { lateral margin of opis- } \\
\text { thonotum }\end{array}$ & $\begin{array}{l}\text { situated vertically to } \\
\text { lateral margin of opis- } \\
\text { thonotum }\end{array}$ & $\begin{array}{l}\text { situated vertically } \\
\text { to lateral margin } \\
\text { of opisthonotum }\end{array}$ & $\begin{array}{l}\text { situated vertically } \\
\text { to lateral margin } \\
\text { of opisthonotum }\end{array}$ \\
\hline Pore Po2 & $\begin{array}{l}\text { located between setae } \\
Z 2 \text { and } S 1\end{array}$ & $\begin{array}{l}\text { located between setae } \\
S 1 \text { and } R 3 \text {, closer to } S 1\end{array}$ & $\begin{array}{l}\text { located between } \\
\text { setae } Z 2 \text { and } S 1\end{array}$ & $\begin{array}{l}\text { inside the line } \\
\text { connecting } Z 2 \text { and } \\
S 1, \text { closer to } S 1\end{array}$ \\
\hline Pore Po3 & $\begin{array}{l}\text { located between setae } \\
J 4 \text { and } Z 4\end{array}$ & $\begin{array}{l}\text { located between setae } \\
J 4 \text { and } Z 3\end{array}$ & $\begin{array}{l}\text { located between } \\
\text { setae } J 3 \text { and } Z 4\end{array}$ & $\begin{array}{l}\text { located under the } \\
\text { line connecting } Z 3 \\
\text { and } S 3\end{array}$ \\
\hline
\end{tabular}

Table 3. Altitude preferences of Prozercon species in the Dilek Peninsula-Büyük Menderes Delta National Park.

\begin{tabular}{cccc}
\hline Altitudinal ranges $(\mathrm{m})$ & $\boldsymbol{P}$. didimensis sp. nov. & $\boldsymbol{P}$. umidicola Urhan, 2002 & P. yavuzi Urhan, 1998 \\
\hline $0-50$ & + & + \\
\hline $50-100$ & & + \\
\hline $100-150$ & + & + \\
\hline $150-200$ & & + \\
\hline $200-250$ & + \\
\hline $300-350$ & + \\
\hline $350-400$ & \\
\hline $400-450$ & \\
\hline $450-500$ & + \\
\hline $500-550$ & \\
\hline $550-600$ & \\
\hline $600-650$ & \\
\hline $650-700$ & \\
\hline $700-750$ & \\
\hline $750-800$ & \\
\hline $800-850$ & \\
\hline $900-950$ & \\
\hline $950-1000$ & \\
\hline
\end{tabular}


Table 4. Habitat preferences of Prozercon species in the Dilek Peninsula-Büyük Menderes Delta National Park.

\begin{tabular}{lccc}
\hline Habitat types & P. didimensis sp. nov. & P. umidicola Urhan, 2002 & P. yavuzi Urhan, 1998 \\
\hline Olea europaea & + & + & \\
\hline Pistacia sp. & + & & + \\
\hline Pinus brutia & & + & + \\
\hline Pinus nigra & & & \\
\hline Quercus sp. & & \\
\hline
\end{tabular}

Key to Prozercon species in the Dilek Peninsula-Büyük Menderes Delta National Park

1 All marginal setae on opisthonotum pilose or plumose. Seta $S 4$ present 2

$\mathbf{1}^{\prime}$ All marginal setae on opisthonotum (except seta S1) short, smooth and needle-like. Seta $S 4$ absent P. yavuzi Urhan, 1998

2 Marginal setae on opisthonotum with seven pairs ( $S 1+$ $R 1-R 6)$, seta $Z 5$ situated as parallel to posterior margin of opisthonotum P. didimensis sp. nov.

$2^{\prime}$ Marginal setae on opisthonotum with seven pairs ( $S 1+$ $R 1-R 7)$, seta $Z 5$ situated as vertically to posterior margin of opisthonotum P. umidicola Urhan, 2002

Altitude preferences of Prozercon species in the Dilek Peninsula-Büyük Menderes Delta National Park

All materials for the Prozercon species were collected from suitable forestland areas at the altitude from 0 to $1000 \mathrm{~m}$ a.s.l. All sampling areas were divided according to 50 meters elevation ranges. After identification processes in the laboratory, the altitudinal distribution results of the Prozercon species were marked in Table 3.

According to Table 3, P. didimensis sp. nov. occurs only at lower altitudes (50-100 m a.s.l.). In addition, P. umidicola was only found at 450-500 m a.s.l. zones. However, since $P$. yavuzi showed a wide range of occurrences from 100 to $850 \mathrm{~m}$ a.s.l., it has no clear preference in terms of altitudinal ranges, but can live in low to mid-land areas.

Habitat preferences of Prozercon species in the Dilek Peninsula-Büyük Menderes Delta National Park

Samplings for Prozercon species were carried out in 97 different localities and the following 23 habitat types, mostly tree species, were noted: broom (Genista sp.), carob (Ceratonia siliqua), fern (Pteridium aquilinum), hawthorn (Crataegus sp.), juniper (Juniperus sp.), mastic (Pistacia sp.), moss (unspecified), mullein (Verbascum sp.), myrtle (Myrtus communis), oak (Quercus sp.), oleaster-leafed pear (Pyrus elaeagrifolia), olive (Olea europaea), pine (Pinus brutia and P. nigra), raspberry (Rubus sp.), rockrose (Cistus sp.), shrub (Daphne gnidioides), strawberry tree (Arbutus sp.), sycamore (Platanus orientalis), tamarisk (Tamarix sp.), thorn (Paliurus spinachristi), thorny burnet (Sarcopoterium spinosum) and walnut (Juglans regia). Habitat preferences of Prozercon species were marked in Table 4.
According to Table 4, all Prozercon specimens were found only in five different habitats (Olea europaea, Pistacia sp., Pinus brutia, P. nigra and Quercus sp.). In the remaining habitats, no specimens of Prozercon were found.

\section{Authors' contributions}

Büşra Keçeci: Investigation, collection of specimens (lead), methodology (equal), writing - original draft (supporting), preservation. Raşit Urhan: Funding acquisition, methodology (equal), project administration, supervision (lead), collection of specimens (supporting), identification, illustration. Mehmet Karaca: Data curation, formal analysis, methodology (equal), supervision (supporting), writing - original draft (lead), writing - review \& editing, collection of specimens (supporting).

\section{Statement of ethics approval}

Not applicable.

\section{Funding}

Present study was financially supported by the Scientific and Technological Research Council of Turkey (TÜBİTAK), project number: $118 Z 101$.

\section{Conflict of interest}

No potential conflict of interest was reported by the authors.

\section{Acknowledgements}

We would like to express our sincere gratitude to TÜBİTAK for their financial support to this study. Also, we are grateful to General Directorate of Nature Conservation and National Parks, Ministry of Agriculture and Forestry, Republic of Turkey that provided the necessary permissions for field surveys and three anonymous referees for their valuable comments to the early version of the manuscript. This study is a part of first author's M.Sc. thesis. Summary of this study was presented as oral presentation and published as an abstract at the $2^{\text {nd }}$ International Eurasian Conference on Science, Engineering and Technology (EurasianSciEnTech 2020), which was held on 7-9 October 2020 at the Gaziantep University (Turkey).

\section{REFERENCES}

Bulut, D.R. 2020. Systematic investigations on zerconid mites (Acari, Zerconidae) of Buharkent, Karacasu and 
Kuyucak Counties (Aydın). Unpublished M.Sc. Thesis, Pamukkale University, Institute of Sciences, Department of Biology, Denizli, 111 pp. [In Turkish]

Johnston, D.E. and Moraza, M.L. 1991. The idiosomal adenotaxy and poroidotaxy of Zerconidae (Mesostigmata: Zerconina). In: F. Dusbábek and V. Bukva (eds). Modern Acarology. Academia, Prague, Czech Republic, 2: 346-356.

Karaca, M. 2015. Systematic studies on zerconid mites (Acari, Mesostigmata, Zerconidae) of Thrace Region (Turkey). Unpublished Ph.D. Thesis, Pamukkale University, Institute of Sciences, Department of Biology, Denizli, 288 pp. [In Turkish]

Karaca, M. 2021. Zerconid mites (Acari: Mesostigmata: Zerconidae) of the Kazdağ National Park, Turkey, with altitude and habitat preferences of the species. Biharean Biologist. Article No: e201207

Karaca, M., Ordoukhanian, C., Ahadiyat, A. and Urhan, R. 2017. New occurrences of zerconid mites (Acari: Zerconidae) from Iran, with checklist and a key to the Iranian species. International Journal of Acarology, 43 (8): 603-611.

doi: $10.1080 / 01647954.2017 .1373857$

Keçeci, B. 2020. Systematic investigations on zerconid mites (Acari, Zerconidae) in the Dilek Peninsula-Büyük Menderes Delta National Park (Aydın). Unpublished M.Sc. Thesis, Pamukkale University, Institute of Sciences, Department of Biology, Denizli, 112 pp. [In Turkish]

Lindquist, E.E. and Evans, G.0. 1965. Taxonomic concepts in the Ascidae, with a modified setal nomenclature for the idiosoma of the Gamasina (Acarina: Mesostigmata). Memoirs of the Entomological Society of Canada, S47: 5-66.

doi: $10.4039 /$ entm $9747 \mathrm{fv}$

Lindquist, E.E. and Moraza, M.L. 1998. Observations on homologies of idiosomal setae in Zerconidae (Acari: Mesostigmata), with modified notation for some posterior body setae. Acarologia, 39: 203-226.

Ujvári, Z. 2008. Zerconid mites (Acari: Mesostigmata: Zerconidae) from Crete, Greece, with description of two new species. Opuscula Zoologica Budapest, 39: 99-108.
Ujvári, Z. 2011. Six new species of Prozercon Sellnick, 1943 (Acari, Mesostigmata, Zerconidae) from Greece, with remarks on the genus. Zootaxa, 2785: 1-31. doi: 10.11646/zootaxa.2785.1.1

Urhan, R. 1998. Some new species of the family Zerconidae (Acari, Mesostigmata) from Turkey. Journal of Natural History, 32: 533-543. doi: 10.1080/00222939800770291

Urhan, R. 2002. New zerconid mites (Acari: Gamasida: Zerconidae) from Turkey. Journal of Natural History, 36: 2127-2138. doi: $10.1080 / 00222930110089166$

Urhan, R. 2010. Two new species of zerconid mites from Turkey, Zoology in the Middle East, 50 (1): 111-118. doi: 10.1080/09397140.2010.10638420

Urhan, R. and Karaca, M. 2019. A new species of the genus Zercon (Acari, Mesostigmata, Zerconidae) from Kastamonu, Turkey. Acarological Studies, 1 (1): 3-10.

Urhan, R. and Karaca, M. 2020. First finding of Prozercon bulgariensis Ujvári, 2013 (Acari, Zerconidae) from Turkey. International Journal of Scientific and Technological Research, 6 (7): 91-97. doi: 10.7176/JSTR/6-07-10

Urhan, R., Karaca, M. and Duran, E.H. 2015. Prozercon banazensis sp. nov. (Acari: Mesostigmata: Zerconidae), a new species of zerconid mite from Turkey, with a new record. Turkish Journal of Zoology, 39 (6): 10111017.

doi: 10.3906/zoo-1501-42

Urhan, R., Karaca, M. and Duran, E.H. 2020. Description of Prozercon miraci sp. nov. (Acari: Mesostigmata: Zerconidae) from Coastal Aegean Section in Turkey, with a key to the Turkish species. Acarological Studies, 2 (1): 18-23.

Urhan, R., Duran, E.H. and Karaca, M.2021. Three new species of Zercon C. L. Koch, 1836 (Acari: Zerconidae) from Coastal Aegean Section of Turkey. Journal of Natural History, in press.

doi: 10.1080/00222933.2020.1844328

Edited by: Salih Doğan

Reviewed by: Three anonymous referees

Citation: Keçeci, B., Urhan, R. and Karaca, M. 2021. Mites of the genus Prozercon (Acari: Zerconidae) in Dilek PeninsulaBüyük Menderes Delta National Park (Turkey), with description of a new species. Acarological Studies, 3 (1): $37-$ 42. 